\title{
Biomarkers and staging of bipolar disorder: a systematic review
}

\author{
Dos biomarcadores ao estadiamento do transtorno bipolar: \\ uma revisão sistemática
}

\author{
Ângela Roda, ${ }^{1}$ Inês Chendo, ${ }^{2}$ Mauricio Kunz ${ }^{3}$
}

\begin{abstract}
Introduction: A growing body of evidence suggests that bipolar disorder (BD) is a progressive disease according to clinical, biochemical and neuroimaging findings. This study reviewed the literature on the relationship between specific biomarkers and BD stages.

Methods: A comprehensive literature search of MEDLINE and PubMed was conducted to identify studies in English and Portuguese using the keywords biomarker, neurotrophic factors, inflammation, oxidative stress, neuroprogression and staging models cross-referenced with bipolar disorder.

Results: Morphometric studies of patients with BD found neuroanatomic abnormalities, such as ventricular enlargement, grey matter loss in the hippocampus and cerebellum, volume decreases in the prefrontal cortex and variations in the size of the amygdala. Other studies demonstrated that serum concentrations of neurotrophic factors, inflammatory mediators and oxidative stress may be used as BD biomarkers.

Conclusions: The analysis of neurobiological changes associated with $\mathrm{BD}$ progression and activity may confirm the existence of $\mathrm{BD}$ biomarkers, which may be then included in staging models that will lead to improvements in treatment algorithms and more effective, individually tailored treatment regimens. Biomarkers may also be used to define early interventions to control disease progression.
\end{abstract}

Keywords: Bipolar disorder, neuroimaging changes, neurotrophic factors, inflammation, oxidative stress, staging.

\begin{abstract}
Resumo
Introdução: Níveis crescentes de evidência sugerem que o transtorno bipolar (TB) exibe um caráter progressivo, em nível tanto clínico, quanto bioquímico e neuroimagiológico. Este estudo revisa a literatura existente sobre a relação entre biomarcadores específicos e estágios do TB.
\end{abstract}

Métodos: Uma busca extensa da literatura nas bases de dados MEDLINE e PubMed foi conduzida para identificar estudos publicados em inglês e em português utilizando as palavraschave biomarker (biomarcador), neurotrophic factors (fatores neurotróficos), inflammation (inflamação), oxidative stress (estresse oxidativo), neuroprogression (neuroprogressão) e staging models (modelos de estadiamento), em referência cruzada com o termo bipolar disorder (transtorno bipolar).

Resultados: Estudos morfométricos em doentes bipolares mostraram a existência de alterações neuroanatômicas, tais como o alargamento dos ventrículos, a perda de substância cinzenta no hipocampo e no cerebelo, a diminuição do volume de determinadas áreas do córtex pré-frontal e variações no tamanho da amígdala. Além disso, outros estudos apontam para a potencialidade do uso dos valores séricos dos fatores neurotróficos, de mediadores inflamatórios e de estresse oxidativo como biomarcadores do TB.

Conclusões: $O$ conhecimento das alterações neurobiológicas, associadas à progressão e atividade do TB, é fundamental para a identificação de biomarcadores. A incorporação de biomarcadores nos modelos de estadiamento do TB poderá permitir um aperfeiçoamento dos algoritmos terapêuticos, possibilitando a elaboração de esquemas de tratamento mais personalizados e eficazes, com destaque para a importância da intervenção precoce na atenuação da progressão da doença.

Descritores: Transtorno bipolar, alterações neuroimagiológicas, fatores neurotróficos, inflamação, estresse oxidativo, estadiamento.

\footnotetext{
${ }^{1}$ Faculdade de Medicina de Lisboa, Lisbon, Portugal. ${ }^{2}$ Psychiatrist, University Clinic, Faculdade de Medicina de Lisboa, Lisboa, Portugal. ${ }^{3}$ MD, PhD. Professor, Department of Psychiatry, School of Medicine, Universidade Federal do Rio Grande do Sul (UFRGS), Porto Alegre, RS, Brazil.

This paper was based on the first author's Master's dissertation (same title), presented on March 21st 2014 at Faculdade de Medicina de Lisboa, Lisbon, Portugal. Financial support: none.

Submitted Feb 21 2014, accepted for publication Jul 22 2014. No conflicts of interest declared concerning the publication of this article.

Suggested citation: Roda A, Chendo I, Kunz M. Biomarkers and staging of bipolar disorder: a systematic review. Trends Psychiatry Psychother. 2014;37(1):3-8. http://dx.doi.org/10.1590/2237-6089-2014-0002. Epub Dec 09, 2014.
} 


\section{Introduction}

Bipolar disorder (BD) is a chronic, often serious psychiatric disease with a prevalence of $1 \%$ to $3 \%$ worldwide. ${ }^{1}$ According to the World Health Organization, $\mathrm{BD}$ is the 12th most important cause of disability in the world, ${ }^{2}$ and its morbidity and mortality are significant. The reduction of mean life expectancy in BD is the result of the high rate of suicides, clearly associated with mood disorders, ${ }^{3}$ and the increased prevalence of medical comorbidities, such as heart disease, diabetes, obesity and thyroid dysfunction, ${ }^{4}$ found in over $80 \%$ of the patients. ${ }^{5}$

A growing body of evidence suggests that $\mathrm{BP}$ is a progressive disease. ${ }^{6-8}$ In 1899 Emil Kraepelin found that the intervals between mood episodes become successively shorter as the number of previous episodes increases. The same author described that, after a certain number of recurrences, episodes tend to occur more spontaneously, in contrast with initial episodes, which are usually triggered by psychosocial stress factors. $7,9,10$ The increase of the number of mood episodes is associated with poorer responses to psychopharmacological treatment.6,8,11-13 Moreover, changes in cognitive functions are more marked in advanced stages of the disease than in controls and in patients in the initial phases of this psychiatric disorder. ${ }^{8}$ Recent studies also showed that cognitive dysfunction and functional deterioration persist even during the euthymic periods in the advanced stages of the disease. ${ }^{14,15}$ These clinical findings may be understood as a result of the neuroprogressive events that occur during the long course of BD. Neuroprogression involves a pathologic reorganization of the central nervous system (CNS) and is, therefore, associated with structural and functional changes of the neural substrate, which is involved in mood regulation. ${ }^{8}$ Several studies have demonstrated that, in addition to the progression of clinical presentations, there are also biochemical and structural changes that confirm neuroprogression, as biological and neuroimaging patterns are different between the initial and the final phases of BD. 6,16

The identification of neurobiological and neuroimaging changes associated with BD progression and activity is fundamental for the definition of biomarkers. Together with a clear understanding of the clinical course of the disease, the definition of biomarkers is fundamental for the development of staging models. BD staging models should be based on the progression from an at-risk to a more severe and refractory presentation and should classify patients according to different stages (I to IV). A staging system should be used in clinical practice to select the most appropriate treatment and define early interventions that may control BD progression. ${ }^{17}$
This study reviewed the literature about neuroimaging and neurobiological abnormalities in patients with BD as potential BD biomarkers. The analysis of neurobiological changes will focus on the role of neurotrophic factors, inflammatory mediators and oxidative stress in $\mathrm{BD}$ physiopathology, activity and progression, and the importance of BD staging will be reviewed.

\section{Methods}

A comprehensive literature search of MEDLINE and PubMed was conducted to identify studies in English and Portuguese using the keywords biomarker, neurotrophic factors, inflammation, oxidative stress, neuroprogression and staging models cross-referenced with bipolar disorder. One hundred and fifty-two articles published from 1899 to 2013 were retrieved. Selection for inclusion was based primarily on the information found in the study abstracts. Moreover, the bibliographies of the selected articles were analyzed. Finally, studies published by experts in this area were also examined. Two articles were excluded because they were written in a language other than English or Portuguese. Other studies were excluded because they did not investigate serum or imaging biomarkers and BD staging.

\section{Results}

\section{Potential BD biomarkers}

According to the definition adopted by the Biomarkers Definitions Working Group, a biomarker is a "characteristic objectively measured and evaluated as an indicator of normal biological processes, pathogenic processes, or pharmacologic responses to a therapeutic intervention." ${ }^{18}$ Biomarkers may be genes, proteins or other molecules, as well as morphological characteristics, associated with physiological or biological mechanisms. ${ }^{19}$ They may be used for several purposes, such as defining prognosis and risk of developing a disease, monitoring response to treatment, establishing new therapeutic targets and elucidating unclear physiopathological processes. ${ }^{19-21}$ In $\mathrm{BD}$, biomarkers seem to be important to evaluate disease activity and progression associated with different moods (mood biomarkers), as well as to identify specific characteristics of the disease (trait biomarkers). ${ }^{19,22}$

Serum biomarkers have several advantages: easy collection, low cost, wide availability and possibility of use in large-scale studies.

Studies that investigated serum biomarkers of BD found that neurotrophins, inflammatory factors and 
oxidative stress are potential candidates. At the same time, neuroimaging studies found that certain changes in patients with $\mathrm{BD}$ might be potential BD biomarkers.

\section{Potential BD neuroimaging biomarkers}

The existence of changes in the brain structures of patients with BD has been largely reported in several studies. Morphometric studies of patients with BD found enlargements of the lateral and third ventricles. ${ }^{23,24}$ However, abnormal ventricular volumes are not evident from the onset of the disease and are often found only after several mood episodes. In fact, Strakowski et al. reported that the volume of ventricles in patients with $\mathrm{BD}$ during the first manic episode was similar to that of healthy individuals, whereas enlarged ventricles were a significant finding only in multiple-episode patients. Eight years after disease onset, lateral ventricles were $122 \%$ larger than at the time of the first episode. ${ }^{24}$ The same study found that first-episode patients had a larger putamen than healthy individuals, although the difference from multiple-episode patients was not significant. The authors concluded that changes in putamen volume were not associated with BD progression. Nevertheless, studies should investigate whether this may be a neuroanatomic marker of BD traits or vulnerability, particularly if this finding is replicated in family members not affected by the disease. ${ }^{24}$

Other studies found a progressive decline in hippocampal and cerebellar gray matter density in people with $\mathrm{BD}$. As the volume of these structures is smaller in patients with multiple mood episodes than in first-episode patients, the decline in hippocampal and cerebellar gray matter density may be a marker of disease progression. ${ }^{25}$ In the same line of investigation, Brambilla et al. found an inverse correlation between cerebellar vermis volume and number of BD episodes. ${ }^{26}$

Several studies also found a reduction in the volume of some areas of the prefrontal cortex..$^{23,27}$ However, the results of several other studies do not always confirm it. ${ }^{19}$ López-Larson et al. found that although the volume of the prefrontal lobe of patients with $\mathrm{BD}$ is similar to that of healthy individuals, there are differences in volume of gray matter in both the right and left prefrontal cortex. Their findings also showed that disease duration may be correlated with a smaller volume of gray matter in the left inferior prefrontal cortex. ${ }^{28}$

In addition to the neurostructural abnormalities mentioned above, an increase in the size of the amygdala was also found in adults with BD. ${ }^{29}$ However, studies with children and adolescents with BD have found a decline in amygdala volume. ${ }^{30,31}$ According to Hallahan et al., the size of the amygdala is smaller in patients after the first mood episode and in patients not treated with lithium. ${ }^{32}$ Therefore, the increase in amygdala volume, the focus of several studies, ${ }^{33-36}$ seems to be associated with treatment with lithium. ${ }^{32,37}$

Finally, numerous studies have documented the existence of white matter hyperintensities in individuals with BD. The presence of these abnormalities in deep white matter is about 2.5 times more likely to be found in individuals with BD than in healthy individuals. ${ }^{38}$ Gulseren et al. reported that the number of total brain hyperintensities increases with the number of manic episodes. The same authors suggested that these lesions should be used as a biological BD marker because white matter hyperintensities are frequent findings in family members that do not have BD. ${ }^{39}$

\section{Potential serum BD biomarkers}

\section{Neurotrophic factors}

Neurotrophic factors are a family of essential growth factors for neurogenesis and neuronal differentiation and survival. Neurotrophins also play an important role in synaptic plasticity and modulation of neuronal excitability. ${ }^{40,41}$ To this date, more than 50 neural growth factors have been identified. ${ }^{42}$ Some other important neurotrophins are the neuronal growth factor, brain derived neurotrophin factor (BDNF), neurotrophin 3 (NT3) and neurotrophin 4 (NT-4). ${ }^{43}$

BDNF, the most abundant neurotrophin in the CNS, has a particularly high expression in the amygdala, hippocampus and prefrontal cortex, brain areas associated with the regulation of emotion and several cognitive functions, such as attention, memory and executive functioning. ${ }^{19,44,45}$ The role of BDNF in BD pathogenesis has been extensively investigated. ${ }^{41,44}$ Recent studies suggested that BDNF might also be used as a biomarker of this mood disorder. Some of these studies showed evidence of promising properties of serum BDNF as a biomarker of BD state. The metaanalyses conducted by Lin and Fernandes et al. indicated that patients in the manic or depressive phase had lower blood concentrations of BDNF than healthy individuals, and that serum BDNF concentrations in euthymic patients were not significantly different from those found in controls. ${ }^{45,46}$ These results suggest that serum BDNF may be a potential biomarker of acute episodes. Additionally, preliminary studies by Fernandes et al. found that serum BDNF concentrations differentiate patients in a manic or depressive state from those in a euthymic phase, at a sensitivity of $90 \%$ and a specificity of $85 \% .{ }^{45}$

In contrast, a recent study found that laboratory measurements of serum BDNF concentrations may distinguish bipolar from unipolar depression at a 
diagnostic accuracy of $88 \%$ for values equal to or lower than $0.26 \mathrm{pg} / \mathrm{mL}$. The authors compared plasma BDNF concentrations of patients with $\mathrm{BD}$ in a depressive state with patients with unipolar depression, and found that the first group expressed lower levels of BDNF. ${ }^{47}$ Clinically, the difference between bipolar and unipolar depression remains challenging, ${ }^{47}$ as the $\mathrm{BD}$ diagnosis can only be made if the patient has at least one manic or hypomanic episode. ${ }^{48}$ Therefore, blood BDNF concentrations may be an important element to establish the differential diagnosis between these diseases. ${ }^{47}$

Other studies suggest that BDNF may be a biomarker of disease progression and severity. In this sense, BDNF values are inversely correlated with severity of symptoms of patients with BD. ${ }^{49,50}$ To explore the potential of blood BDNF to discriminate advanced and initial BD states, Kapczinski et al. raised the hypothesis that serum BDNF concentrations may discriminate patients with $\mathrm{BD}$ for less than 3 years from patients that have had it for over 10 years, ${ }^{45}$ at a sensitivity of $100 \%$, specificity of $88 \%$ and accuracy of $95 \%$ for values equal to or lower than $0.62 \mathrm{pg} / \mathrm{mL} .{ }^{51}$

Another potential application of serum BDNF concentrations is the prediction of response to treatment and the control of pharmacological efficacy. In fact, Tramontina et al. found that there is a normalization of blood BDNF levels after appropriate treatment of acute mania. ${ }^{52,53}$ Rybakowski and Suwalska, in turn, found that patients with an excellent response to lithium had higher plasma BDNF levels than patients refractory to treatment with this drug. ${ }^{54}$

To clarify the mechanisms that underlie the decline of BDNF levels in patients with BD, several studies have investigated the existence of polymorphisms in the bdnf gene. One of the most frequently investigated polymorphisms is a methionine substitution for valine at codon 66 (val66met) in the region of the promoter of the bdnf gene. However, studies found divergent results when investigating the association between the val66met polymorphism and BD development. ${ }^{55-65}$ Differences in results may indicate that genetic alterations in different ethnic groups, races or populations may confer different levels of susceptibility to BD development. ${ }^{41}$

In addition to BDNF, other neurotrophins are also abnormal in the plasma of patients with BD. Patients with BD have higher serum NT-3 concentrations during mood episodes than euthymic patients or healthy individuals. ${ }^{43,50,66,67}$ Neurotrophin 4/5 (NT-4/5) seems to be persistently higher in the blood of patients with $B D$, regardless of their mood state. ${ }^{43,68}$

\section{Inflammatory factors}

Inflammatory factors, also known as cytokines, are proteins or glycoproteins secreted by cells of the immune system in response to noxious stimuli. In the CNS, cytokines act in specific pathways and are associated with mood control, energy and activity. ${ }^{69}$ Moreover, inflammatory factors interact with the neuroendocrine system, specifically the hypothalamus-hypophysisadrenal axis, the autonomous nervous system and the system of neurotransmitters, which includes dopamine, serotonin and glutamate. ${ }^{69,70}$

In the last years, a growing number of publications have suggested that the immunoinflammatory system may be involved in BD physiopathology. In fact, recent studies with patients with BD confirmed the presence of chronic inflammation in this mood disorder. ${ }^{5}$

In general, mood episodes may be classified as proinflammatory states. ${ }^{43}$ Brietzke et al. found that patients with $B D$ in a manic state had higher inteleukin-2 (IL-2), IL-4 and IL-6 concentrations than controls, whereas in patients with $\mathrm{BD}$ in a depressive state, only the proinflammatory cytokine IL- 6 was elevated. The same authors found that, during euthymic states, only the IL-4 levels were elevated. ${ }^{71}$ These findings suggest that mania and depression, at a lower grade, are associated with a proinflammatory state. ${ }^{72}$ Similarly, Kim et al. found that patients in a manic state have significantly higher concentrations of IL- 6 and tumor necrosis factor alpha (TNF-a) than individuals without BD. After six weeks of treatment with mood stabilizing drugs, the same patients had normal IL- 6 levels, but TNF-a concentrations remained high. Therefore, those authors suggested that IL- 6 might be a marker of manic states. ${ }^{70}$

At the same time, preliminary studies found inflammatory biomarkers capable of discriminating bipolar patients in the initial stage of the disease from those in advanced stages. ${ }^{61}$ According to KauerSant'Anna et al., at advance BD stages, serum IL10 concentrations declined and plasma TNF-a levels increase significantly. ${ }^{16,73}$ Kapczinski et al. found that when TNF-a concentrations were equal to or greater than $20.36 \mathrm{pg} / \mathrm{mL}$, patients with $\mathrm{BD}$ at advanced stages could be discriminated from patients in initial stages of the disease at an accuracy of $91 \%$ and sensitivity and specificity of $97 \%$ and $85 \%,{ }^{51}$ which indicates that TNF-a may be a potential biomarker of BD progression.

In addition to the changes in inflammatory cytokines described above, moderately elevated levels of C-reactive protein are found during manic episodes. ${ }^{74}$ Increased concentrations of proinflammatory cytokines, found in patients with BD, may indicate an association with high rates of medical comorbidities, particular heart disease, ${ }^{5}$ as these inflammatory changes may be risk factors for the development of obesity, hypertension, diabetes and atherosclerosis. ${ }^{75}$ These findings stress the importance of medical evaluations and physical 
control of patients with BD, as well as of the definition of adequate treatments to reduce early deaths associated with BD. Comorbidities seem to be not only a consequence of treatment and life style characteristic of individuals with $\mathrm{BD}$, but also a symptom of this psychiatric disorder. ${ }^{5}$ In fact, medical burden is part of the early stages of BD. ${ }^{5}$ Over $70 \%$ of young individuals with $\mathrm{BD}$ are estimated to need treatment for chronic medical conditions. ${ }^{76}$ Middle-aged individuals with $B D$, in contrast, develop heart disease and hypertension at a younger age than adults without BD. ${ }^{77}$ Therefore, medical burden should be included in BD staging.

\section{Oxidative stress}

Oxidative stress is the result of imbalance between oxidant and antioxidant enzymes, which usually results in cell damage. Lower antioxidant levels and an increased production of pro-oxidant agents give rise to oxidative stress, which leads to changes in macromolecules, such as lipid, proteins, carbohydrates and DNA. ${ }^{43,78}$ The CNS is particularly vulnerable to oxidative lesions, because the brain uses great amounts of oxygen, which promotes the formation of oxygen free radicals and oxygen reactive species. Moreover, the CNS has a limited antioxidant capacity, and glutathione is the main antioxidant in the brain. ${ }^{43,79}$ The antioxidant system is composed of an enzyme, such as superoxide dismutase (SOD), catalase and glutathione peroxidase, and a non-enzyme component, such as glutathione. ${ }^{43}$

The role of oxidative stress in the physiopathology of $\mathrm{BD}$ has been investigated in several studies, which consistently reported changes in antioxidant enzymes, lipid peroxidation and levels of nitric oxide (NO), an important marker of oxidative stress. ${ }^{19,80,81}$

The meta-analysis conducted by Andreazza et al. concluded that some of the oxidative stress markers are elevated in plasma or blood cells of individuals with $\mathrm{BD}$, particularly $\mathrm{NO}$ and thiobarbituric acid reactive substances (TBARS), markers of lipid peroxidation. ${ }^{80}$ The analysis of blood TBARS concentrations in patients with $\mathrm{BD}$ revealed that they are elevated during all stages of BD. ${ }^{82}$ These results suggest that lipid damage occurs all along the course of this mood disorder. ${ }^{80}$ Therefore, these findings suggest that the levels of TBARS may be used as biomarkers of BD progression if future studies confirm that they increase with disease duration. In addition to TBARS, NO concentrations are also elevated in $\mathrm{BD}$, regardless of mood state. ${ }^{19,83}$ Andreazza et al. found that there are other oxidative stress markers, such as 3-nitrotyrosine (3-NT), that are elevated in the initial stages of BD. ${ }^{84}$

However, the results of studies about the antioxidant enzyme system are often discordant.
Andreazza et al. and Kunz et al. found an increased SOD activity in patients during acute BD episodes, but not in euthymic patients. ${ }^{43,82,85}$ Similarly, MachadoVieira et al. reported an increase in the activity of this antioxidant enzyme in unmedicated patients with BD during a manic episode. ${ }^{43,86}$ In contrast, other studies found a decrease in SOD activity during all BD phases, ${ }^{43}$ whereas Raffa et al. did not find any differences in SOD levels between patients with BD and healthy individuals. ${ }^{43,87}$

One of the consequences of oxidative stress is DNA damage, and studies with patients with BD have shown an increase in the frequency of DNA damage. ${ }^{19,43,88}$ Andreazza et al. described a positive correlation between manic and depressive symptom severity and increased DNA damage. ${ }^{88}$ At the same time, DNA damage has also been associated with reductions in telomere length in lymphocytes of individuals with BD. ${ }^{19,89}$ According to Saretzki and Von-Zglinicki, telomere shortening may be indicative of cumulative oxidative stress. ${ }^{90}$ Moreover, a study with patients with $\mathrm{BD}$ concluded that the number of shortened telomeres and mean telomere length are associated with number of depressive episodes along life, but not with type of disease. ${ }^{6,89}$ Telomere shortening physiologically occurs after each cell division as part of normal ageing. However, telomere shortening found in individuals with $\mathrm{BD}$ seems to be indicative of ageing acceleration in about 10 years. These data may explain the association between BD and early medical comorbidities associated with ageing. ${ }^{91}$

Another element to support the role of oxidative stress in $\mathrm{BD}$ is the evidence that antioxidant compounds, such as $\mathrm{N}$-acetylcystein (NAC) are beneficial in the treatment of $\mathrm{BD}$, according to several studies. NAC, a glutathione precursor, efficiently reduces depressive symptoms in patients with $\mathrm{BD}$ and improves their functioning and quality of life. ${ }^{92,93}$

Treatment effects of mood stabilizers seem to be associated with their action upon oxidative stress pathways. ${ }^{19}$ Patients with BD treated with lithium have a significant reduction of TBARS concentrations and of the SOD/CAT ratio, ${ }^{19,89}$ whereas healthy individuals exposed to lithium do not have the same changes. ${ }^{19,94}$ These findings suggest that lithium has an antioxidant effect favorable for the treatment of BD.

To evaluate systemic toxicity in BD, Kapczinski et al. compared the concentrations of several markers in patients with $\mathrm{BD}$, healthy individuals and patients with sepsis. One of their notable findings was the impressive magnitude of oxidative damage during acute BD episodes, as high as the level seen in patients with sepsis in some cases. ${ }^{42,95}$ 


\section{The importance of BD staging}

Staging is a widely used tool in Medicine, particularly in cancer and heart disease, and is the basis for the choice of adequate treatment and the definition of a prognosis. ${ }^{96}$ However, only recently have the first models of staging of psychiatric disorders been developed. ${ }^{97}$

To build staging models, the course of the disease should be predictable along time, ${ }^{96}$ and the disease at the initial stages should usually be associated with a better prognosis and simpler treatment requirements. In addition, treatment efficacy should also be greater in the beginning of the disease, and a subsequent progressive decline should be expected, culminating with resistance to treatment. ${ }^{98}$ For this reason, staging models should be constructed in parallel to treatment algorithms, as several stages usually have different treatment needs. Therefore, staging should guide treatment plans and the definition of prognoses. ${ }^{99}$

In the last years, different staging models have been suggested for BD. In 2007 Berk et al. suggested that $\mathrm{BD}$ develops from an asymptomatic at-risk stage during which risk factors are active (stage 0 ). The next is the prodromal stage, during which symptoms are mild and nonspecific (stage 1). After this stage, the first mood episode, usually a depressive episode, occurs (stage 2 ). The first episode is usually followed by multiple remissions and relapses (stage 3). Finally, individuals with BD may experience a phase characterized by symptom persistence and resistance to treatment, without interepisode symptom remission (stage 4$)^{17,99}$ (Table 1).

The initial model described by Berk et al. was later developed by Kapczinski et al., who, in 2009, suggested the adoption of a staging model that included a latent phase followed by four stages (stages 1 to 4 ). This model describes the progression from a latent (at-risk) stage to a more advanced, treatment-refractory stage. The model developed by Kapczinski et al. requires the longitudinal evaluation of several clinical features, the study of comorbidities, functioning and neurocognition and the definition of biomarkers (Table 1). ${ }^{17,100}$

The staging models described by Berk et al. and Kapczinski et al. are based on the identification of individuals at risk of developing $\mathrm{BD}$ because early diagnosis and treatment may critically improve prognosis. ${ }^{17}$ According to Berk et al., early interventions are fundamental for neuroprotection. ${ }^{101}$ Therefore, the treatment during the initial stages of the disease should primarily focus on neuroprotective strategies, but treatment during more advanced stages should be palliative and rehabilitative to control the consequences of disease progression. ${ }^{99}$ The importance assigned to neuroprotective strategies may take psychiatry to a new era of preventive psychopharmacology. ${ }^{43}$

Table 1 - Suggested staging models (adapted by permission)

\begin{tabular}{|c|c|c|c|c|}
\hline \multicolumn{2}{|c|}{ Berk et al. ${ }^{98}$} & \multicolumn{3}{|c|}{ Kapczinski et al. ${ }^{73,100}$} \\
\hline Stage & Description & Stage & Description & Biomarkers \\
\hline 0 & $\begin{array}{l}\text { Increased risk for mood disorder, } \\
\text { asymptomatic period during which a } \\
\text { set of risk factors are active. }\end{array}$ & Latent & $\begin{array}{l}\text { Mood change symptoms and anxiety; } \\
\text { Increased risk of developing BD; } \\
\text { No cognitive dysfunction. }\end{array}$ & $\begin{array}{l}\text { Genetic polymorphisms may } \\
\text { determine susceptibility. }\end{array}$ \\
\hline $\begin{array}{l}1 \mathbf{a} \\
1 \mathbf{b}\end{array}$ & $\begin{array}{l}\text { Mild or nonspecific symptoms. } \\
\text { Prodromal features: ultra-high risk. }\end{array}$ & 1 & $\begin{array}{l}\text { Well-defined euthymic periods. } \\
\text { No psychiatric morbidity between } \\
\text { episodes. } \\
\text { No cognitive dysfunction. }\end{array}$ & $\begin{array}{l}\text { Serum concentrations: } \\
\uparrow \text { TNF-a } \\
\uparrow 3-N T \\
\uparrow \mathrm{IL}-6, \mathrm{IL}-10\end{array}$ \\
\hline 2 & $\begin{array}{l}\text { First major manic or depressive } \\
\text { (more common) episode. }\end{array}$ & 2 & $\begin{array}{l}\text { Inter-episode symptoms due to } \\
\text { comorbidities. } \\
\text { Transient cognitive dysfunction. }\end{array}$ & $\begin{array}{l}\text { Serum concentrations: } \\
\uparrow \mathrm{TNF}-\mathrm{a} \\
\uparrow 3-\mathrm{NT} \\
\uparrow \mathrm{IL}-6, \mathrm{IL}-10 \\
\downarrow \mathrm{BDNF}\end{array}$ \\
\hline $\begin{array}{l}3 \mathbf{a} \\
3 \mathbf{b}\end{array}$ & $\begin{array}{l}\text { First relapse, subclinical symptoms. } \\
\text { First clinical relapse. }\end{array}$ & 3 & $\begin{array}{l}\text { Clinically relevant pattern of cognitive } \\
\text { and functional impairment (unable } \\
\text { to work) }\end{array}$ & $\begin{array}{l}\text { Morphometric brain abnormalities may } \\
\text { be present. }\end{array}$ \\
\hline 3c & $\begin{array}{l}\text { Subsequent pattern of remissions } \\
\text { and relapses. }\end{array}$ & & & $\begin{array}{l}\uparrow \uparrow \mathrm{TNF}-\mathrm{a} \\
\uparrow 3-\mathrm{NT} \\
\uparrow \mathrm{IL}-6, \mathrm{IL}-10 \\
\downarrow \downarrow \mathrm{BDNF}\end{array}$ \\
\hline 4 & $\begin{array}{l}\text { Refractory to treatment, no } \\
\text { symptom remission. }\end{array}$ & 4 & $\begin{array}{l}\text { Loss of autonomy due to cognitive } \\
\text { and functional impairment. }\end{array}$ & $\begin{array}{l}\text { Ventricular enlargement and/or white } \\
\text { matter hyperintensities. } \\
\uparrow \uparrow \text { TNF-a } \\
\uparrow 3-\mathrm{NT} \\
\downarrow \downarrow \text { BDNF } \\
\uparrow \uparrow \text { Glutathione reductase and } \\
\text { transferase } \\
\downarrow \text { IL-6, IL-10 }\end{array}$ \\
\hline
\end{tabular}

BDNF = brain-derived neurotrophic factor, IL = interleukin, TNF-a = tumor necrosis factor alpha, 3-NT = 3-nitrotyrsosine. 


\section{Conclusions}

Although the physiopathological mechanisms of BD have not been fully clarified, several publications have suggested that neurotrophic and inflammatory factors and oxidative stress may play a role in the pathogenesis of this psychiatric disorder. Recent studies with individuals with BD pointed to the possibility of using plasma concentrations of neurotrophins, inflammatory factors and oxidative stress mediators as biomarkers of $\mathrm{BD}$ progression and activity. At the same time, neuroimaging studies of patients with $B D$ also found structural abnormalities that may be potential $B D$ biomarkers. The adoption of biomarkers to stage $B D$ may improve treatment guidelines and algorithms and lead to the development of more efficient, individually tailored treatment regimens. ${ }^{73}$ However, current literature also points to limitations that should not be ignored. To this date, most studies are cross-sectional, and very few are prospective. Moreover, other psychiatric disorders and neurodegenerative diseases present with biochemical and imaging abnormalities identical to those found in BD, which may compromise the use of isolated biomarkers. Therefore, different combinations of serum concentrations and neuroimaging biomarkers may have to be evaluated to improve their sensitivity and specificity. Finally, study findings should be replicated, and longitudinal studies should be conducted to confirm the clinical and scientific validity of biochemical and neuroanatomic abnormalities as biomarkers of BD.

\section{References}

1. Merikangas $K R$, Jin R, He JP, Kessler RC, Lee S, Sampson NA, et al. Prevalence and correlates of bipolar spectrum disorder in the world mental health survey initiative. Arch Gen Psychiatry. 2011;68:241-51.

2. World Health Organization. The global burden of disease: 2004 update. Geneva: WHO; 2008. http://www.who.int/healthinfo/ global burden disease/2004 report update/en/

3. Angst $\mathrm{F}$, Stassen $\mathrm{HH}$, Clayton PJ, Angst J. Mortality of patients with mood disorders: follow-up over 34-38 years. J Affect Disord. 2002;68:167-81.

4. Kupfer DJ. The increasing medical burden in bipolar disorder. JAMA. 2005;293:2528-30.

5. Leboyer M, Soreca I, Scott J, Frye M, Henry C, Tamouza R, et al. Can bipolar disorder be viewed as a multi-system inflammatory disease? J Affect Disord. 2012;141:1-10. Epub 2012 Apr 11.

6. Fries GR, Pfaffenseller B, Stertz L, Paz AV, Dargél AA, Kunz M, et al. Staging and neuroprogression in bipolar disorder. Curr Psychiatry Rep. 2012;14:667-75.

7. Post RM, Fleming J, Kapczinski F. Neurobiological correlates of illness progression in the recurrent affective disorders. J Psychiatr Res. 2012;46:561-73. Epub 2012 Mar 23.

8. Berk M, Kapczinski F, Andreazza AC, Dean OM, Giorlando F, Maes $M$, et al. Pathways underlying neuroprogression in bipolar disorder: focus on inflammation, oxidative stress and neurotrophic factors. Neurosci Biobehav Rev. 2011;35:804-17. Epub 2010 Oct 8.

9. Kraepelin E. Manic-depressive insanity and paranoia. Edinburgh: E. \& S. Livingstone; 1899

10. Post RM. Mechanisms of illness progression in the recurrent affective disorders. Neurotox Res. 2010;18:256-71.
11. Ketter TA, Houston JP, Adams DH, Risser RC, Meyers AL, Williamson DJ, et al. Differential efficacy of olanzapine and lithium in preventing manic or mixed recurrence in patients with bipolar I disorder based on number of previous manic or mixed episodes. J Clin Psychiatry. 2006;67:95-101.

12. Swann AC, Bowden CL, Calabrese JR, Dilsaver SC, Morris DD. Differential effect of number of previous episodes of affective disorder on response to lithium or divalproex in acute mania. Am ] Psychiatry. 1999;156:1264-6.

13. Scott J1, Paykel E, Morriss R, Bentall R, Kinderman P, Johnson $T$, et al. Cognitive-behavioural therapy for severe and recurrent bipolar disorders: randomised controlled trial. $\mathrm{Br}$ J Psychiatry. 2006;188:313-20.

14. Martínez-Arán A, Vieta E, Colom F, Torrent C, Sánchez-Moreno J, Reinares $M$, et al. Cognitive impairment in euthymic bipolar patients: implications for clinical and functional outcome. Bipolar Disord. 2004;6:224-32

15. Martinez-Aran A, Vieta E, Torrent C, Sanchez-Moreno J, Goikolea JM, Salamero $M$, et al. Functional outcome in bipolar disorder: the role of clinical and cognitive factors. Bipolar Disord. 2007;9:103-13.

16. Kauer-Sant'Anna M, Kapczinski F, Andreazza AC, Bond DJ, Lam RW, Young LT, et al. Brain-derived neurotrophic factor and inflammatory markers in patients with early- vs. late-stage bipolar disorder. Int J Neuropsychopharmacol. 2009;12:447-58. Epub 2008 Sep 4.

17. Vieta $E$, Reinares $M$, Rosa AR. Staging bipolar disorder. Neurotox Res. 2011;19:279-85. Epub 2010 May 12.

18. Biomarkers Definitions Working Group. Biomarkers and surrogate endpoints: preferred definitions and conceptual framework. Clin Pharmacol Ther. 2001;69:89-95.

19. Teixeira AL, Barbosa IG, Machado-Vieira R, Rizzo LB, Wieck A, Bauer ME. Novel biomarkers for bipolar disorder. Expert Opin Med Diagn. 2012;7:147-59. Epub 2012 Dec 16.

20. Puntmann VO. How-to guide on biomarkers: biomarker definitions, validation and applications with examples from cardiovascular disease. Postgrad Med J. 2009;85:538-45.

21. Schwarz E, Bahn S. The utility of biomarker discovery approaches for the detection of disease mechanisms in psychiatric disorders. Br J Pharmacol. 2008;153(Suppl 1):S133-6. Epub 2008 Jan 14.

22. Frey BN, Andreazza AC, Houenou J, Jamain S, Goldstein BI, Frye $M A$, et al. Biomarkers in bipolar disorder: a positional paper from the International Society for Bipolar Disorders Biomarkers Task Force. Aust N Z J Psychiatry. 2013;47:321-32. Epub 2013 Feb 14.

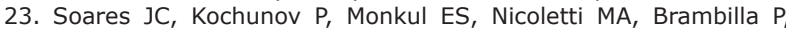
Sassi RB, et al. Structural brain changes in bipolar disorder using deformation field morphometry. Neuroreport. 2005;16:541-4.

24. Strakowski SM, DelBello MP, Zimmerman ME, Getz GE, Mills NP, Ret J, et al. Ventricular and periventricular structural volumes in first- versus multiple-episode bipolar disorder. Am J Psychiatry. 2002;159:1841-7.

25. Moorhead TW, McKirdy J, Sussmann JE, Hall J, Lawrie SM, Johnstone EC, et al. Progressive gray matter loss in patients with bipolar disorder. Biol Psychiatry. 2007;62:894-900. Epub 2007 Jul 9.

26. Brambilla $P$, Harenski $K$, Nicoletti $M$, Mallinger AG, Frank $E$, Kupfer DJ, et al. MRI study of posterior fossa structures and brain ventricles in bipolar patients. J Psychiatr Res. 2001;35:313-22.

27. Blumberg HP, Krystal JH, Bansal R, Martin A, Dziura J, Durkin K, et al. Age, rapid-cycling, and pharmacotherapy effects on ventral prefrontal cortex in bipolar disorder: a cross-sectional study. Biol Psychiatry 2006;59:611-8. Epub 2006 Jan 18.

28. López-Larson MP, DelBello MP, Zimmerman ME, Schwiers ML, Strakowski SM. Regional prefrontal gray and white matter abnormalities in bipolar disorder. Biol Psychiatry. 2002;52:93-100.

29. Beyer JL, Krishnam KR. Volumetric brain imaging findings in mood disorders. Bipolar Disord. 2002;4:89-104.

30. Chang K, Karchemskiy A, Barnea-Goraly N, Garrett A, Simeonova DI, Reiss A. Reduced amygdalar gray matter volume in familial pediatric bipolar disorder. J Am Acad Child Adolesc Psychiatry. 2005;44:565-73.

31. DelBello MP, Zimmerman ME, Mills NP, Getz GE, Strakowski SM. Magnetic resonance imaging analysis of amygdala and other subcortical brain regions in adolescents with bipolar disorder. Bipolar Disord. 2004;6:43-52.

32. Hallahan B, Newell J, Soares JC, Brambilla P, Strakowski SM, Fleck $D E$, et al. Structural magnetic resonance imaging in bipolar disorder: an international collaborative mega-analysis of individual adult patient data. Biol Psychiatry. 2011;69:326-35. Epub 2010 Oct 27.

33. Altshuler LL, Bartzokis G, Grieder T, Curran J, Mintz J. Amygdala enlargement in bipolar disorder and hippocampal reduction in 
schizophrenia: an MRI study demonstrating neuroanatomic specificity. Arch Gen Psychiatry. 1998;55:663-4.

34. Altshuler LL, Bartzokis G, Grieder T, Curran J, Jimenez T, Leight K, et al. An MRI study of temporal lobe structures in men with bipolar disorder or schizophrenia. Biol Psychiatry. 2000;48:147-62.

35. Brambilla P, Harenski K, Nicoletti M, Sassi RB, Mallinger AG, Frank $E$, et al. MRI investigation of temporal lobe structures in bipolar patients. J Psychiatr Res. 2003;37:287-95.

36. Strakowski SM, DelBello MP, Sax KW, Zimmerman ME, Shear $\mathrm{PK}$, Hawkins JM, et al. Brain magnetic resonance imaging of structural abnormalities in bipolar disorder. Arch Gen Psychiatry. 1999;56:254-60.

37. Foland LC, Altshuler LL, Sugar CA, Lee AD, Leow AD, Townsend J, et al. Increased volume of the amygdala and hippocampus in bipolar patients treated with lithium. Neuroreport. 2008;19:221-4.

38. Kempton MJ, Geddes JR, Ettinger U, Williams SC, Grasby PM. Meta-analysis, database, and meta-regression of 98 structural imaging studies in bipolar disorder. Arch Gen Psychiatry. 2008;65:1017-32.

39. Gulseren S, Gurcan M, Gulseren L, Gelal F, Erol A. T2 hyperintensities in bipolar patients and their healthy siblings. Arch Med Res. 2006;37:79-85.

40. Lu B, Pang PT, Woo NH. The yin and yang of neurotrophin action. Nat Rev Neurosci. 2005;6:603-14.

41. Post RM. Role of BDNF in bipolar and unipolar disorder: clinical and theoretical implications. J Psychiatr Res. 2007;41:979-90. Epub 2007 Jan 18

42. Magalhães PV, Fries GR, Kapczinski F. [Peripheral markers and the pathophysiology of bipolar disorder]. Rev Psiquiatr Clin. 2012;39:60-7.

43. Pfaffenseller B1, Fries GR, Wollenhaupt-Aguiar B, Colpo GD, Stertz L, Panizzutti B, et al. Neurotrophins, inflammation and oxidative stress as illness activity biomarkers in bipolar disorder. Expert Rev Neurother. 2013;13:827-42.

44. Teixeira AL, Barbosa IG, Diniz BS, Kummer A. Circulating levels of brain-derived neurotrophic factor: correlation with mood, cognition and motor function. Biomark Med 2010;4:871-87.

45. Fernandes BS, Gama CS, Ceresér KM, Yatham LN, Fries GR, Colpo $\mathrm{G}$, et al. Brain-derived neurotrophic factor as a state-marker of mood episodes in bipolar disorders: a systematic review and meta-regression analysis. J Psychiatr Res. 2011;45:995-1004.

46. Lin PY. State-dependent decrease in levels of brain-derived neurotrophic factor in bipolar disorder: a meta-analytic study. Neurosci Lett. 2009;466:139-43. Epub 2009 Sep 26.

47. Fernandes BS, Gama CS, Kauer-Sant'Anna M, Lobato MI, Belmonte-de-Abreu P, Kapczinski F. Serum brain-derived neurotrophic factor in bipolar and unipolar depression: a potential adjunctive tool for differential diagnosis. J Psychiatr Res. 2009;43:1200-4. Epub 2009 Jun 6.

48. American Psychiatric Association. Diagnostic and Statistical Manual of Mental Disorders. 5th ed. Arlington, VA: American Psychiatric Publishing; 2013.

49. Cunha AB, Frey BN, Andreazza AC, Goi JD, Rosa AR, Gonçalves $C A$, et al. Serum brain-derived neurotrophic factor is decreased in bipolar disorder during depressive and manic episodes. Neurosci Lett. 2006;398:215-9. Epub 2006 Feb 9.

50. Grande I, Fries GR, Kunz M, Kapczinski F. The role of BDNF as a mediator of neuroplasticity in bipolar disorder. Psychiatry Investig. 2010;7:243-50.

51. Kapczinski F, Fernandes BS, Kauer-Sant'Anna M, Gama CS, Yatham LN, Berk M. The concept of staging in bipolar disorder: the role of BDNF and TNF-alpha as biomarkers. Acta Neuropsychiatr 2009;21:272-4.

52. Tramontina JF, Andreazza AC, Kauer-Sant'anna M, Stertz L, Goi $J$, Chiarani $F$, et al. Brain-derived neurotrophic factor serum levels before and after treatment for acute mania. Neurosci Lett. 2009;452:111-3. Epub 2009 Jan 15.

53. Kapczinski $F$, Dal-Pizzol $F$, Teixeira AL, Magalhaes PV, KauerSant'Anna M, Klamt F, et al. Peripheral biomarkers and illness activity in bipolar disorder. J Psychiatr Res. 2011;45:156-61. Epub 2010 Jun 11.

54. Rybakowski JK1, Suwalska A. Excellent lithium responders have normal cognitive functions and plasma BDNF levels. Int J Neuropsychopharmacol. 2010;13:617-22. Epub 2010 Apr 15.

55. Sklar P, Gabriel SB, McInnis MG, Bennett P, Lim Y-, Tsan G, et al. Family-based association study of 76 candidate genes in bipolar disorder: BDNF is a potential risk locus. Brain-derived neutrophic factor. Mol Psychiatry. 2002;7:579-93.

56. Neves-Pereira M, Mundo E, Muglia P, King N, Macciardi F, Kennedy $\mathrm{JL}$. The brain-derived neurotrophic factor gene confers susceptibility to bipolar disorder: evidence from a family-based association study. Am J Hum Genet. 2002;71:651-5. Epub 2002 Aug 2.

57. Geller B, Badner JA, Tillman R, Christian SL, Bolhofner K, Cook $\mathrm{EH}$ Jr. Linkage disequilibrium of the brain-derived neurotrophic factor Val66Met polymorphism in children with a prepubertal and early adolescent bipolar disorder phenotype. Am J Psychiatry. 2004; $161: 1698-700$.

58. Skibinska M, Hauser J, Czerski PM, Leszczynska-Rodziewicz A, Kosmowska M, Kapelski $P$, et al. Association analysis of brainderived neurotrophic factor (BDNF) gene Val66Met polymorphism in schizophrenia and bipolar affective disorder. World J Biol Psychiatry. 2004;5:215-20.

59. Lohoff FW, Sander T, Ferraro TN, Dahl JP, Gallinat J, Berrettini WH. Confirmation of association between the Val66Met polymorphism in the brain-derived neurotrophic factor (BDNF) gene and bipolar I disorder. Am J Med Genet B Neuropsychiatr Genet. 2005;139B:51-3.

60. Green EK, Raybould R, Macgregor S, Hyde S, Young AH, O'Donovan $M C$, et al. Genetic variation of brain-derived neurotrophic factor (BDNF) in bipolar disorder: case-control study of over 3000 individuals from the UK. Br J Psychiatry. 2006;188:21-5.

61. Strauss J, Barr CL, George CJ, King N, Shaikh S, Devlin B, et al. Association study of brain-derived neurotrophic factor in adults with a history of childhood onset mood disorder. Am J Med Genet B Neuropsychiatr Genet. 2004;131B:16-9.

62. Nakata $K$, Ujike $H$, Sakai A, Uchida N, Nomura A, Imamura $T$, et al. Association study of the brain-derived neurotrophic factor (BDNF) gene with bipolar disorder. Neurosci Lett. 2003;337:17-20.

63. Hong CJ, Huo SJ, Yen FC, Tung CL, Pan GM, Tsai SJ. Association study of a brain-derived neurotrophic-factor genetic polymorphism and mood disorders, age of onset and suicidal behavior. Neuropsychobiology. 2003;48:186-9.

64. Kunugi $H$, Iijima $Y$, Tatsumi $M$, Yoshida $M$, Hashimoto $R$, Kato $T$, et al. No association between the Val66Met polymorphism of the brain-derived neurotrophic factor gene and bipolar disorder in a Japanese population: a multicenter study. Biol Psychiatry. 2004;56:376-8.

65. Neves-Pereira M, Cheung JK, Pasdar A, Zhang F, Breen G, Yates $P$, et al. BDNF gene is a risk factor for schizophrenia in a Scottish population. Mol Psychiatry. 2005;10:208-12.

66. Walz JC, Andreazza AC, Frey BN, Cacilhas AA, Ceresér KM, Cunha $A B$, et al. Serum neurotrophin-3 is increased during manic and depressive episodes in bipolar disorder. Neurosci Lett. 2007;415:87-9. Epub 2007 Jan 17.

67. Fernandes BS, Gama CS, Walz JC, Ceresér KM, Fries GR, Colpo G, et al. Increased neurotrophin-3 in drug-free subjects with bipolar disorder during manic and depressive episodes. J Psychiatr Res. 2010;44:561-5. Epub 2010 Jan 8.

68. Walz JC, Magalhães PV, Giglio LM, Cunha AB, Stertz L, Fries GR, et al. Increased serum neurotrophin-4/5 levels in bipolar disorder. J Psychiatr Res. 2009;43:721-23. Epub 2008 Dec 10.

69. Brietzke E, Kapczinski F. TNF-alpha as a molecular target in bipolar disorder. Prog Neuropsychopharmacol Biol Psychiatry. 2008;32:1355-61. Epub 2008 Jan 16.

70. Kim YK, Jung HG, Myint AM, Kim H, Park SH. Imbalance between pro-inflammatory and anti-inflammatory cytokines in bipolar disorder. J Affect Disord. 2007;104:91-5. Epub 2007 Apr 16.

71. Brietzke E, Stertz L, Fernandes BS, Kauer-Sant'anna M, Mascarenhas $M$, Escosteguy Vargas $A$, et al. Comparison of cytokine levels in depressed, manic and euthymic patients with bipolar disorder. J Affect Disord. 2009;116:214-7. Epub 2009 Feb 28.

72. Hamdani N, Doukhan R, Kurtlucan O, Tamouza R, Leboyer M. Immunity, inflammation, and bipolar disorder: diagnostic and therapeutic implications. Curr Psychiatry Rep. 2013;15:387.

73. Kapczinski F1, Dias VV, Kauer-Sant'Anna M, Brietzke E, Vázquez $\mathrm{GH}$, Vieta $\mathrm{E}$, et al. The potential use of biomarkers as an adjunctive tool for staging bipolar disorder. Prog Neuropsychopharmacol Biol Psychiatr. 2009;33:1366-71. Epub 2009 Aug 8.

74. Dickerson F, Stallings C, Origoni A, Boronow J, Yolken R. Elevated serum levels of C-reactive protein are associated with mania symptoms in outpatients with bipolar disorder. Prog Neuropsychopharmacol Biol Psychiatry. 2007;31:952-5. Epub 2007 Mar 6.

75. Drake C, Boutin H, Jones MS, Denes A, McColl BW, Selvarajah JR, et al. Brain inflammation is induced by co-morbidities and risk factors for stroke. Brain Behav Immun. 2011;25:1113-22. Epub 2011 Feb 26.

76. Evans-Lacko SE, Zeber JE, Gonzalez JM, Olvera RL. Medical comorbidity among youth diagnosed with bipolar disorder in the United States. J Clin Psychiatry. 2009:70:1461-6. Epub 2009 Sep 8. 
77. Goldstein BI, Kemp DE, Soczynska JK, McIntyre RS. Inflammation and the phenomenology, pathophysiology, comorbidity, and treatment of bipolar disorder: a systematic review of the literature. J Clin Psychiatry. 2009;70:1078-90. Epub 2009 Jun 2.

78. Halliwell B, Gutteridge JM. Free Radicals in Biology and Medicine. 4th ed. New York: Oxford University Press; 2007.

79. Olmez I, Ozyurt H. Reactive oxygen species and ischemic cerebrovascular disease. Neurochem Int. 2012;60:208-12. Epub 2011 Nov 22.

80. Andreazza AC, Kauer-Sant'anna M, Frey BN, Bond DJ, Kapczinski F, Young LT, et al. Oxidative stress markers in bipolar disorder: a metaanalysis. J Affect Disord. 2008;111:135-44. Epub 2008 Jun 9.

81. Frey BN, Andreazza AC, Kunz M, Gomes FA, Quevedo J, Salvador $M$, et al. Increased oxidative stress and DNA damage in bipolar disorder: a twin-case report. Prog Neuropsychopharmacol Biol Psychiatry. 2007;31:283-5. Epub 2006 Jul 20.

82. Andreazza AC, Cassini C, Rosa AR, Leite MC, de Almeida LM, Nardin P, et al. Serum S100B and antioxidant enzymes in bipolar patients. J Psychiatr Res. 2007;41:523-9. Epub 2006 Sep 7.

83. Savas HA, Gergerlioglu HS, Armutcu F, Herken H, Yilmaz HR, Kocoglu $E$, et al. Elevated serum nitric oxide and superoxide dismutase in euthymic bipolar patients: impact of past episodes. World J Biol Psychiatry. 2006; 7:51-5.

84. Andreazza AC, Kapczinski F, Kauer-Sant'Anna M, Walz JC, Bond DJ, Gonçalves CA, et al. 3-Nitrotyrosine and glutathione antioxidant system in patients in the early and late stages of bipolar disorder. J Psychiatry Neurosci. 2009;34:263-71.

85. Kunz M, Gama CS, Andreazza AC, Salvador M, Ceresér KM, Gomes $F A$, et al. Elevated serum superoxide dismutase and thiobarbituric acid reactive substances in different phases of bipolar disorder and in schizophrenia. Prog Neuropsychopharmacol Biol Psychiatry. 2008;32:1677-81. Epub 2008 Jul 6.

86. Machado-Vieira R, Andreazza AC, Viale CI, Zanatto V, Cereser $V \mathrm{Jr}$, da Silva Vargas $\mathrm{R}$, et al. Oxidative stress parameters in unmedicated and treated bipolar subjects during initial manic episode: a possible role for lithium antioxidant effects. Neurosci Lett. 2007;421:33-6. Epub 2007 May 22.

87. Raffa M, Barhoumi S, Atig F, Fendri C, Kerkeni A, Mechri A. Reduced antioxidant defense systems in schizophrenia and bipolar I disorder. Prog Neuropsychopharmacol Biol Psychiatry. 2012;39:371-5. Epub 2012 Jul 27.

88. Andreazza AC, Frey BN, Erdtmann B, Salvador M, Rombaldi F, Santin A, et al. DNA damage in bipolar disorder. Psychiatry Res. 2007:153:27-32. Epub 2007 Jun 20.

89. Elvsăshagen T, Vera E, Bøen E, Bratlie J, Andreassen OA, Josefsen $D$, et al. The load of short telomeres is increased and associated with lifetime number of depressive episodes in bipolar II disorder. J Affect Disord. 2011;135:43-50. Epub 2011 Aug 30.

90. Saretzki, G, Von-Zglinicki T. Replicative aging, telomeres, and oxidative stress. Ann N Y Acad Sci. 2002;959:24-9.
91. Simon NM1, Smoller JW, McNamara KL, Maser RS, Zalta AK, Pollack $\mathrm{MH}$, et al. Telomere shortening and mood disorders: preliminary support for a chronic stress model of accelerated aging. Biol Psychiatry. 2006;60:432-5. Epub 2006 Apr 11.

92. Berk M, Copolov DL, Dean O, Lu K, Jeavons S, Schapkaitz I, et al. $\mathrm{N}$-acetyl cysteine for depressive symptoms in bipolar disorder--a double-blind randomized placebo-controlled trial. Biol Psychiatry. 2008;64:468-75. Epub 2008 Jun 5.

93. Magalhães PV, Dean OM, Bush AI, Copolov DL, Malhi GS, Kohlmann $\mathrm{K}$, et al. N-acetylcysteine for major depressive episodes in bipolar disorder. Rev Bras Psiquiatr. 2011;33:374-8.

94. Khairova R, Pawar R, Salvadore G, Juruena MF, de Sousa RT, Soeiro-de-Souza MG, et al. Effects of lithium on oxidative stress parameters in healthy subjects. Mol Med Report. 2012;5:680-2. Epub 2011 Dec 22.

95. Kapczinski $F$, Dal-Pizzol $F$, Teixeira AL, Magalhaes PV, KauerSant'Anna M, Klamt F, et al. A systemic toxicity index developed to assess peripheral changes in mood episodes. Mol Psychiatry. 2010;15:784-6. Epub 2010 Mar 30.

96. Berk M, Berk L, Dodd S, Cotton S, Macneil C, Daglas R, et al. Stage managing bipolar disorder. Bipolar Disord. 2014;16:471-7. Epub 2013 Jun 20.

97. McGorry PD, Purcell R, Hickie IB, Yung AR, Pantelis C, Jackson $\mathrm{HJ}$. Clinical staging: a heuristic model for psychiatry and youth mental health. Med J Aust. 2007;187(7 Suppl):S40-2.

98. Berk M, Hallam KT, McGorry PD. The potential utility of a staging model as a course specifier: a bipolar disorder perspective. J Affect Disord. 2007; 100:279-81. Epub 2007 Apr 11.

99. Berk M, Conus P, Lucas N, Hallam K, Malhi GS, Dodd S, et al. Setting the stage: from prodrome to treatment resistance in bipolar disorder. Bipolar Disord. 2007;9:671-8.

100.Kapczinski F1, Dias VV, Kauer-Sant'Anna M, Frey BN, GrassiOliveira R, Colom F, et al. Clinical implications of staging bipolar disorders. Expert Rev Neurother. 2009;9:957-66.

101.Berk M, Malhi GS, Hallam K, Gama CS, Dodd S, Andreazza AC, et al. Early intervention in bipolar disorders: clinical, biochemical and neuroimaging imperatives. J Affect Disord. 2009;114:1-13.

\section{Correspondence:}

Ângela Roda

Faculdade de Medicina de Lisboa

Av. Professor Egas Moniz

1649-028 - Lisbon, Portugal

E-mail: angela.neto.roda@gmail.com 